Reframing the Vernacular: Politics, Semiotics, and Representation 
Gusti Ayu Made Suartika • Julie Nichols

Editors

\section{Reframing the Vernacular: Politics, Semiotics, and Representation}

鱼 Springer 


\section{Editors}

Gusti Ayu Made Suartika Masters Program in Architecture and Development \& Planning Udayana University Denpasar, Bali, Indonesia

\section{Julie Nichols}

School of Art, Architecture and Design, Vernacular Knowledge Research Group University of South Australia Adelaide, SA, Australia

\section{ISBN 978-3-030-22447-9 \\ ISBN 978-3-030-22448-6 (eBook) https://doi.org/10.1007/978-3-030-22448-6}

(C) Springer Nature Switzerland AG 2020

This work is subject to copyright. All rights are reserved by the Publisher, whether the whole or part of the material is concerned, specifically the rights of translation, reprinting, reuse of illustrations, recitation, broadcasting, reproduction on microfilms or in any other physical way, and transmission or information storage and retrieval, electronic adaptation, computer software, or by similar or dissimilar methodology now known or hereafter developed.

The use of general descriptive names, registered names, trademarks, service marks, etc. in this publication does not imply, even in the absence of a specific statement, that such names are exempt from the relevant protective laws and regulations and therefore free for general use.

The publisher, the authors, and the editors are safe to assume that the advice and information in this book are believed to be true and accurate at the date of publication. Neither the publisher nor the authors or the editors give a warranty, express or implied, with respect to the material contained herein or for any errors or omissions that may have been made. The publisher remains neutral with regard to jurisdictional claims in published maps and institutional affiliations.

This Springer imprint is published by the registered company Springer Nature Switzerland AG. The registered company address is: Gewerbestrasse 11, 6330 Cham, Switzerland 


\section{Foreword}

Vernacular architecture is contextual and particular in respect to place, geography and culture. Vernacular buildings and settlements involve uses of local resources, respond to local climate and produce regional and local identities. Rapid development, uncontrolled growth, urbanization and other forces of change have profound impacts on vernacular architecture. The challenges that face vernacular architecture are many. They range from commodification of culture through the use of vernacular building forms and appropriations of traditional materials by the tourist industry to mindless imitations of vernacular building elements so as to invent national or regional identities. As we become more global we also face the challenge of how to conserve, preserve and sustain local vernacular building practices and unique regional architectural and settlement characteristics. Within this context of continuity and change, discourses pertaining to the role and uses of vernacular architecture in terms of political contexts, meaning, and representation have not been adequately addressed as "themes" within contemporary conversations on vernacular architecture.

The First International Conference on Cultural Communication and Space (ICCCS) and the Ninth International Conference on Vernacular Settlements (ISVS) held at the Department of Architecture, Udayana University in Bali, Indonesia, November 28-29, 2018, brought together scholars and professionals from a wide variety of disciplines to participate in an international dialogue involving these less developed themes. Framed within the context of "vernacularity" and "culture" the conference attracted a wide range of scholars and professionals from a variety of disciplines to collectively focus on two areas. The first was our understanding of vernacularity in the context of "globalization, cross-disciplinarity, and development." The second was to discuss how "vernacularity has been treated, used, employed, manipulated, practiced, maintained, learned, reconstructed, preserved and conserved, at the level of individual and community experience." 
Papers presented by participants in the conference addressed topics categorized into the following sub-themes:

- Transformation in the vernacular built environment

- Vernacular architecture and representation

- The meaning of home

- Symbolic intervention and interpretation of vernacularity

- The semiotics of place

- The politics of ethnicity and settlement

- Global tourism and its impacts on vernacular settlement

- Vernacular built form and aesthetics

- Technology and construction in vernacular built forms

- Vernacular language - writing and oral traditions

This book is a collection of papers from the conference. The scholarly writings and research investigations that make up this book represent a rich tapestry of case studies, points of view, arguments and readings that examine and reframe the complexities the vernacular within the frameworks of politics, semiotics, and representation. Together, the chapters in this book present a multi-disciplinary and international discourse about the place, relevance, perceptions, transformations and contemporary usefulness of vernacular built environments.

Department of Architecture

Texas Tech University

Lubbock, TX, USA
Joseph Aranha joseph.aranha@ttu.edu 


\section{Preface}

The word vernacular is widely circulated. The Oxford English Dictionary defines the word as "the language or dialect spoken by ordinary people in a particular country or region", or in regard to the built environment, vernacular implies "architecture concerned with domestic and functional rather than monumental buildings". The use of the word vernacular has also been extended generically to embrace vernacular music, vernacular sport, vernacular crafts, vernacular literature, vernacular art, vernacular modernism, etc. In so doing, a variety of academic disciplines have become involved, to include architecture, anthropology, linguistics, cultural studies, and other regions of academic endeavour. Paradoxically, language itself also reveals other problems - some cultures do not have a word for vernacular and interpret implied meanings differently. We cannot even assume that an agreed cross-cultural meaning exists - some languages do not have the word vernacular in their dictionaries.

So vernacular has an immense range of meanings and contexts. Possibly, its widest use is in the area of vernacular architecture, a subject already explored in great depth. The purpose of this conference is to investigate three lesser developed themes: The first is the political context of vernacular subjects (such as architecture). The second addresses meaning in the vernacular. The third deals with how the vernacular is presented and represented. But we also know that these three regions overlap in complex ways and address a wide variety of themes. We seek to address such complexity by focussing on the interstices between subjects rather than on individual subjects such as architecture, culture, language, art, or design.

The word vernacular also conveys a state of being native, original, and contextual to geography and places. In many locations, it embraces entire environments, their art, culture, and the very existence of indigenous societies. How the word is to be comprehended is a moot point, but how a vernacular existence is to be understood and accommodated by postmodernity is a herculean task involving debate at an archaeology of levels. Hence, "vernacularity" is also part of the global equation. It has been a source of political and social conflict and dispute for decades over issues such as the survival of indigenous communities in places like Australia. The commodification of people and places, the strategy of global tourism, has deep 
impacts on vernacular life, its customs, traditions, aspirations, and sensibilities. Accepting the inevitability of globalisation and its universal impacts on local cultures, we need to go no further than the conference venue in Bali to witness its effects. Here, we can observe the erosion of traditions, the designation of traditional villages as tourist destinations, the establishment of World Heritage Sites, and overall the redeployment of urban meaning to focus on the global over the local.

Given the complexity of the above situation, it is the prime goal of this conference to reflect this context and to invite participants from a wide variety of disciplines to participate in an international dialogue on "vernacularity" and culture. The conference therefore seeks to concentrate on two major domains. First, it attempts to reframe our understanding of vernacularity by addressing the subject in the context of globalisation, cross-disciplinarity, and development. Second, it discusses the phenomenon of how vernacularity has been treated, used, employed, manipulated, practiced, maintained, learned, reconstructed, preserved, and conserved at the level of individual and community experience. We therefore invite scholars from a wide variety of knowledge fields to participate in enriching and engaging discussions as to how both agendas can be addressed.

This international gathering has been initiated collaboratively by the Centre for Cultural Communication and Space (CCCS), the Research Centre for Smart City, Tropical Engineering-Architecture Program, and Master's Program in Architecture of Udayana University, the University of South Australia and its Vernacular Knowledge Research Group (VKRG), and the International Society for Vernacular Settlement (ISVS). This event is also following the successful conduct of the 8th ISVS International Conference by the Department of Architecture of Hasanudin University in Makassar, Sulawesi, in 2016.

This international conference involved four keynote speakers including Emeritus Professor Anthony Reid (Australian National University, Australia), Emeritus Professor John Lang (University of New South Wales, Australia), Professor Abidin Kusno (York University, Canada), and Professor Ramesh Biswas (Austria). It has produced publications in the form of conference proceedings and journal articles. This scholarly work published by Springer represents the first category.

Denpasar, Indonesia

Gusti Ayu Made Suartika

Adelaide, Australia Julie Nichols

May 2019 


\section{Contents}

1 Reframing the Vernacular and Other Tales . . . . . . . . . . . 1 Abidin Kusno

$2 \quad$ Landfill Vernacular. . . . . . . . . . . . . . . . . . . 13 John Devlin

3 'Bale Kulkul' Architecture as the Representation of Balinese Autonomy Tradition Christina Gantini

4 Cultural Burning and the Interstices of Two Vernacular Cultural Forms

Campbell Drake

5 The Effects 'Share-Economy' Based Accommodation Service on Vernacular Settlement (Case Study: Yogyakarta's Sultanate Palace Complex)

Trias Mahendarto

6 The Shift of Symbolic Meaning of Joglo Houses for People in Brayut Tourism Village

Purwanto Hadi, Vincentia Reni Vitasurya, and Eduardus Kevin Pandu

7 Designing for Vernacular Landscape Through Ecosystem-Approach: A Case of Floating Settlements at Dal Lake, Kashmir

Tanya Talwar and Sanjeev Singh

8 Place Making and Ordering Life. Case Study:

The Bali Aga Village, Pengotan

Himasari Hanan and Dwinik Winawangsari 
9 Identifying Local Builders' Roles in Physical Transformation of Minangkabau's Rumah Gadang . . . . . . . . . . . . . . . . . . . 97

Feni Kurniati, Hafsah Salamah, and Sri Suryani

10 Transformation in Vernacular Architecture of Baiga Tribe of Central India . . . . . . . . . . . . . . . . . . . . . . . . . . . 107

Shikha Patidar, Brishbhanlali Raghuwanshi, and Sonal Tiwari

11 Meaning, Time, Communication: Reflecting on the "Aceh Method" and Vernacular . . . . . . . . . . . . . . . . . . . 127

Julie Nichols and Darren Fong

12 Identity Representation and Conflict Prevention in Community Mosques of Malang Raya, East Java, Indonesia. . . . . . . 143 Yulia Eka Putrie and Widjaja Martokusumo

13 Transformation Versus Preservation of Vernacular Architecture in Bali: A Lesson from Bali Aga Villages .

Tri Anggraini Prajnawrdhi

14 Coping Strategies in Vernacular Architecture: Adaptation and Adjustment for Contemporary Needs at Pinggan Village, Kintamani, Bali.

Antonius Karel Muktiwibowo and Made Wina Satria

15 Vernacularity and Place: Re-presentation of Fishing Huts of Bahrain at the Venice Biennale Ranjith Dayaratne

16 Relation of Binary Opposition Structure (Rwa-Bhineda)

Mount-Ocean: A Case Study on Cultural Heritage of Pura

Batukaru-Pakendungan/Tanah Lot in the Perspective of Ecofeminism in Bali

I. Nyoman Wardi

17 Preventive Measures and Formulas for the Sustainability of Vernacular Settlements in Malaysia

Nor Zalina Harun, Nur 'Adilah Hassan, and Noordeyana Tambi

18 Physical Attributes Significant in Preserving the Social Sustainability of the Traditional Malay Settlement . .

Nor Zalina Harun, Najiha Jaffar, and Puteri Shireen Jahn Kassim

19 Revisiting the Minangkabau Traditional House in the Central Area of Sumatra: The Case of Limapuluh Koto and Bangkinang.

Muhammar Khamdevi 
20 The Influence of Cultural Acculturation on Architecture Keraton Kasepuhan Cirebon . . . . . . . . . . . . . . . . . . . . . 251

S. Anggraeni Dyah and Farhan Kahirillah Zein

21 Transformation of Traditional Vernacular Settlements:

Lessons from the Kathmandu Valley . . . . . . . . . . . . . . . . 261

Chandani KC, Sadasivam Karuppannan, and Alpana Sivam 